Original Research Paper

\title{
Android Based House Mart Application
}

\author{
*Bayu Kanigoro, Afan Galih Salman and Anthony \\ School of Computer Science, Bina Nusantara University, Jakarta, Indonesia
}

\author{
Article history \\ Received: 19-04-2021 \\ Revised: 26-06-2021 \\ Accepted: 19-07-2021 \\ Corresponding Author: \\ Bayu Kanigoro \\ School of Computer Science, \\ Bina Nusantara University, \\ Jakarta, Indonesia \\ Email: bkanigoro@binus.edu
}

\begin{abstract}
Several marketing media outlets do not offer adequate information regarding the homes they sell to fulfill property sellers' needs. In addition, purchasers find it difficult to find homes that meet their criteria because media marketing is less effective. Therefore, the purpose of this research is to create an Android-based mobile application capable of making it easier for owners and buyers to advertise and quest for homes. This research employed the study design methods for gathering information, empirical, literature reviews and design methods. The result showed that owners and buyers need better additional promotional media to make things easier for sellers when advertising properties for sale while ensuring buyers find homes that suit their needs. This application is designed to promote users' abilities to sell and buy houses easily.
\end{abstract}

Keywords: Android, Mobile Application, E-Marketplace

\section{Introduction}

Housing, which refers to the construction and assigned usage of houses or buildings collectively, is a natural right to shelter people. In recent years, it is becoming tasking to locate a place to live in the Jakarta region due to the construction of high-rise buildings such as malls and commercial apartments. Although housing has become available, locating homes that meet the needs of individuals is quite challenging. Potential buyers seek homes put up for sales through newspapers, magazines, or website advertisements. However, this impedes the search for homes because too much time is spent examining existing advertisements in various newspapers, with some revealing misleading information. Furthermore, several home sales advertisements are not properly delivered due to the shortage of adequate promotional media.

Over time, diverse human needs and the willingness to get work done within a short period led to the continuous development in information technology to meet today's community's needs (Bauer, 2005). One of the emerging fields of information systems is mobile technology. Its establishment has led to the increase in mobile phones' use by various communities ranging from school children, college to Indonesian office staff, particularly within the capital city of Jakarta. Nowadays, mobile phones facilitate information delivery and are much more enticing, portable and handy in accelerating various jobs (Kharisma, 2011). Besides that, existing applications certainly support individual activities fields, especially in entertainment, education and industry.
Housing is an essential human need, however, existing information, through print and electronic media, remains inadequate due to its inability to convey it correctly entirely. Therefore, users need an application that provides a feature for exchanging information about home sales in detail for sellers wishing to sell their homes and for prospective buyers to obtain information and find their dream home.

Therefore, this research focused on designing and developing an application that facilitates users' housing searching process. Due to the increasing number of mobile phone users, it is more useful to base this application on mobile applications. Furthermore, this promotional and property search application is better off based on Android technology, which is increasingly fast, challenging and widely recognized. The features of the application in this research are as follows:

1. Advertisement and housing search system

2. Urban search criteria are limited to price range, housing area scope, land range and house area

3. Limited to Jakarta province

4. User interactions include phone numbers and email addresses

5. The location of the property is seen by connecting to google maps

6. Offline and online modes are enabled when the user is either not connected or connected to the server, respectively. In offline mode (before signing in), there is a feature to view previously saved home information and information earlier uploaded. Meanwhile, in online mode (after signing in), there are 
several additional features for searching and uploading house information with a list of uploaded ones

7. The application utilized the Android 9 OS (Pie)

This study contributes to designing an android-based mobile phone app to help people obtain relevant, easy and fast information regarding their property and as a versatile alternative advertising tool for sellers. This promotion and property search application in the Jakarta area is intended to act as a useful tool to the surrounding community and make it simpler for users to obtain and provide the necessary information on their property, making it easier to find. The application to be made is expected to help utilized users' productivity in locating properties suitable for their daily needs.

This promotional and property search application is for the advantage of the surrounding community in the Jakarta area. It makes it easier for a user to obtain and provide required information on a property, thereby making it easier to obtain information regarding a community's property according to their specific criteria, especially in the Jakarta regions.

This research is related to several publications, such as Darmansyah et al. (2021), which focused on mobile application development for renting boarding rooms in the Karawang region. Their study is relevant because numerous industries are located in the region and many people from other provinces temporarily move into the region for work. The current method for searching and renting rooms in the region is by asking friends, checking the surrounding community and visiting the advertised houses individually. Darmansyah et al. (2021) research led to the development of web-based applications that run on mobile devices using a browser. However, this research developed an Android operating system focused on general property/housing, which is one of Parpati's research weaknesses. Furthermore, their research does not have a searching feature for locating houses of interest. Research carried out by Kurniawan et al. (2018) focused on SMS gateway for fishery product transactions between customers. This is not adequate for users to look at a house based on price due to SMS technology limitations.

\section{Methodology}

In this mobile application development, the approach used is data collection, analysis, library research, design and development. Data were collected through surveys and interviews (Connolly and Begg, 2010; Pressman, 2005). Survey stages distribute questionnaires to several respondents currently selling and searching for property in the Jakarta area. A series of questions was prepared for participants. The information collected is the participant's preference for a mobile application, which makes it easy to advertise and search for property. It also provides the main details needed by participants when searching for homes, information regarding those willing to sell their homes and additional details. At the interviewing stage, a list of questions was prepared for participants that have tested the developed application for feedback. The input obtained is to determine the application's ability to promote and search for user benefits and disadvantages, such as their difficulty using the application and user suggestions. The analytical method was used to interpret questionnaires and interview outcomes.

In this research, the literature study intended to gather knowledge or evidence from books and articles on current issues. The modeling process was carried out using a screen design method, class, case, sequence and activity diagrams (Pressman, 2005). Development approaches carried out using the incremental process model (Pressman, 2005) start by gathering user needs, planning application development, modeling, product design and implementation.

The questionnaire's findings to 25 respondents were used to identify users willing to sell their properties. The result showed that $100 \%$ use mobile phones, $52 \%$ often use application features found on mobile phones, $100 \%$ search for a place to live. Furthermore, 23 and $32 \%$ use the Internet and print media to access home information for sale, while $39 \%$ find it difficult to use any type of information.

Based on the problem and user analysis findings, it is seen that house sellers and buyers also find it challenging to use the promotion and search application. Lack of special property media does not present consumers' knowledge reasonably well and easily. The mass channels do not support the number of property promotion advertisement to publish these advertisements, therefore, they are not broadcast properly.

User survey results also indicate it most people use mobile phones more frequently for their daily needs. Unfortunately, there is no unique mobile application to advertise homes. Therefore, it is simpler for users to advertise their homes by introducing mobile phone applications capable of carrying out this process. The application built needs, to sum up, all user needs to be extracted from their findings.

The application created includes a system to promote and search for houses needed by sellers and prospective buyers. Those wishing to sell their homes post their house data for potential buyers. To facilitate the selling process, a feature is provided for photos of the house to be taken and uploaded directly from a mobile phone. The seller is also given the feature to first save the house's data that is posted before completing the process, which does not take time. Prospective homebuyers easily find a house through the application, created with a map displayed to determine its location. Furthermore, prospective buyers also have the ability to save the desired home data for later viewing without using internet access. 
The application includes a system of search and sale of homes, enabling the seller to input the associated data for buyer to easily access. In addition to entering information, sellers directly take photos of their homes through their cell phone cameras or upload them from their phone gallery. Furthermore, the seller also has the ability to save the house to be posted in advance, assuming it is incomplete, or directly post the complete one. Before posting data, users must first log into the promotion and search system of this residence. When an error occurs while entering data, sellers have the ability to edit the posted data. The process of posting home data does not take a long time.

Prospective buyers that have logged in are able to immediately search for homes through the application. After acquiring the desired home information, they view the information, along with a map with the property's location. Prospective buyers are also able to save the desired home data for later viewing without the need to login. They also have the ability to dial the seller's telephone number provided in the listing.

This promotion and home search application are used on cell phones based on the Android operating system developed using the Java programming language. The web server is built using the Hibernate framework (Chen and Liu, 2009; Konda, 2014; Wu et al., 2010), which is also supported by the Java programming language. Database applications are needed to manage data from application users. The database application used on the server-side and mobile phones is MySQL and SQLite, respectively (Owens, 2006). Furthermore, the mobile phone application is based on Android 2.2 (Froyo) (Shanker and Lai, 2011). This mobile phone application is connected to the web service via a SOAP connection (Kangasharju et al., 2003). Meanwhile, the Back End website application uses the JSP programming language (Steelman, 2008) with Servlet and JavaScript technology (Liu and Xiong, 2014).

The application architecture used is the Three-Tier Client-Server architecture, as shown in Fig. 1. It comprises three layers, namely the user interface, application and web servers. The user interface layer is the form of an Androidbased cellular phone application for users. Application server layer in the form of a web server for back-end development, through web services and servlets and performs data processing logic using the Hibernate framework.

The flow and system design of the application is shown in Fig. 2 and 3. Users (sellers and buyers) are able to create a new account by pressing the Registration button on the Home page. The user needs to fill in personal data in the fields available on the Registration form. Furthermore, they are opportune to press the Register button for registration or press the Cancel button to decline the process and return to the Home page.

The application uses the Binary Search algorithm to search property results based on users' parameters (Knuth, 1973) as shown in Alg. 1. The parameters are based on
Kisaran Harga (Price Range), Kisaran Luas Bangunan (Building Area Range), Kisaran Luas Tanah (Land Area Range). It accepts the user's first choice in the parameter before running the algorithm. The property records stored in a form of array $P$ of $n$ elements $P_{0}, P_{1}$, $P_{2}, \ldots, P_{n-1}$. The array is sorted such that $P_{0} \leq P_{1} \leq P_{2} \leq$ $\ldots \leq P_{n-1}$ and $\beta$ is the target value.

Users (sellers and buyers) that already have an account log in by pressing the Login button on the Home page after filling in their Username and Password.

Sellers are opportune to sell new homes through the Sell Houses menu on the Home page. The need to fill three forms, namely the Enter Photo, the Enter Data and the Enter Regional forms. After filling out these forms, they save the home data to a file or upload it to the database server.

The seller visualizes the file containing some data of the house for sale, created on the selling house page that has not been uploaded, through the file menu on the Home page before or after login. When one of the file list data houses is selected, a file detail page appears consisting of three tabs. The Info tab displays the house's main information for sales, such as title, address, price and photo. The details tab display more complete home information. In contrast, the map tab displays a map of the location of the house for sale. The housing data is uploaded to the database server when the seller logs in and are connected to the internet. However, when the user touches and holds one of the file list data, an options menu appears which edit or delete the data.

$$
\begin{aligned}
& \text { procedure BINARY } \operatorname{SeARch}(P, n, \beta) \\
& l \leftarrow 0 \\
& r \leftarrow n-1 \\
& \text { while } l \leq r \text { do } \\
& m \leftarrow\left\lfloor\frac{l+m}{2}\right\rfloor \\
& \text { if } P_{m}<\beta \text { then } \\
& l \leftarrow m+1 \\
& \text { else if } P_{m}>\beta \text { then } \\
& r \leftarrow m-1 \\
& \text { else } \\
& \text { return } m \\
& \text { end if } \\
& \text { end while } \\
& \text { return }-1 \\
& \text { end procedure }
\end{aligned}
$$

Alg. 1: Searching algorithm used for property search in the application 
The seller has the ability to edit home information stored in a file by selecting Edit on the options menu. On the Edit file page, the seller edits photos, data, or areas of the house for sale, then press the Save button to save it or the Cancel button to cancel and return to the file page. The seller can delete the data stored in the file by selecting Delete on the options menu. Data that has been deleted no longer appear in the file list. Furthermore, the seller visualizes the data of the house put up for sale through the My Sell List menu on the Home page after login. The seller chooses the Unsold menu to determine the number of unsold homes or selects the Already Sold menu on My Sell List to display the list of sold homes. When one of the data houses in the Unsold List or List Already Sold list is selected, a Home detail page appears consisting of three tabs, namely the Info, the Details and the Map. When the user selects one of the Unsold List data, the selection menu appears to Mark Sold, Edit and Delete the data. The seller changes the status of the house for sale by selecting Mark Sold on the options menu. They also have the ability to edit the home information on the Sold List by selecting Edit in the options menu. On the Edit Home Data page, the seller edits photos, data, or areas of the house for sale, then press the Upload button to save the data to the database server or press the Cancel button to cancel editing home data and return to the My Sales-List page.
Users manage accounts through the Account Settings menu, which displays data and enables them to edit passwords or contacts by pressing the Edit Password or Edit Contact buttons. On the Edit Password page, the user needs to fill in the old and desired new passwords, then press the Edit button to save it or the Cancel button to cancel. On the Edit Contact page, users are their email and phone number, then press the Edit button to save email and phone number changes or the Cancel button for cancelation.

Application users that use Android-based cellular phones are able to exchange data with a web server through web service access such as SOAP. The data sent to the application is converted to an XML format that supports WSDL on the webserver. This request and response data is entered into an envelope which is part of SOAP for it to be accessed by the application or the webserver. The Back End uses a web browser connected to the internet to access the webserver, with the website created using JSP and JSTL. Furthermore, data is the exchange between the browser and the web server using Servlet. Web servers use the Hibernate framework as an intermediary for interaction between Java applications and the database server. Data obtained from the database server is accommodated using POJO classes, which are accessed later by DAO.

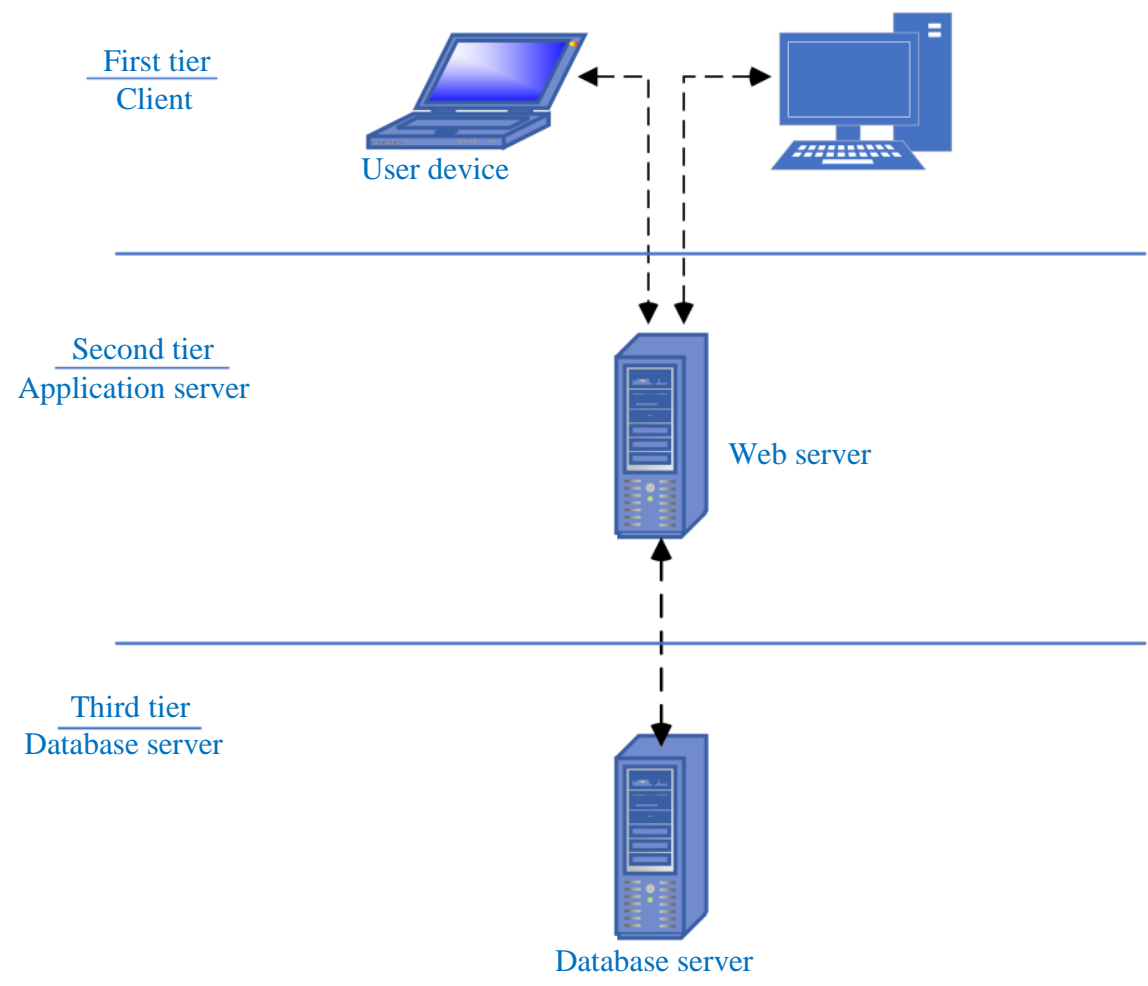

Fig. 1: Three-tier architecture of the application 


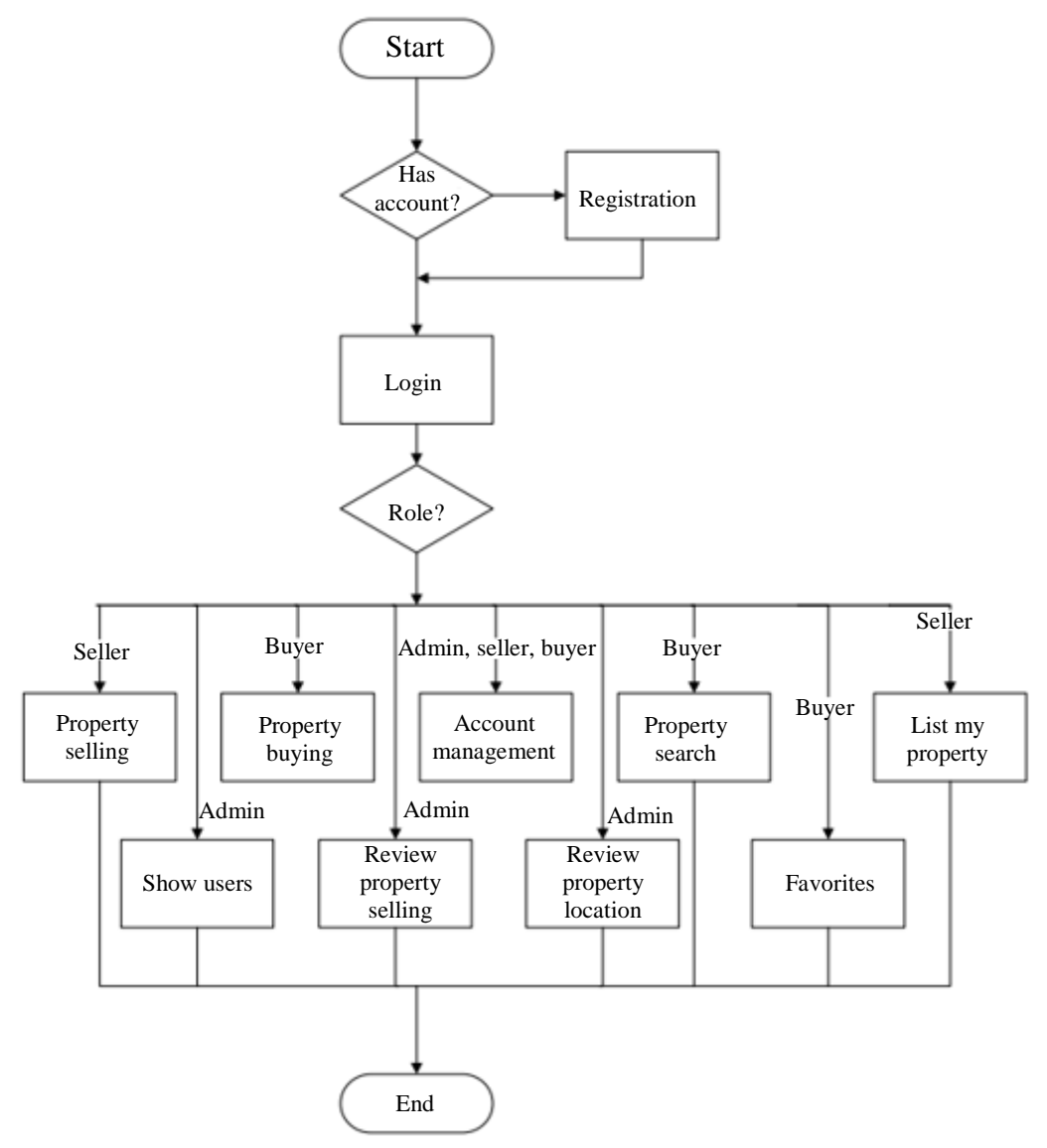

Fig. 2: Flow of the application

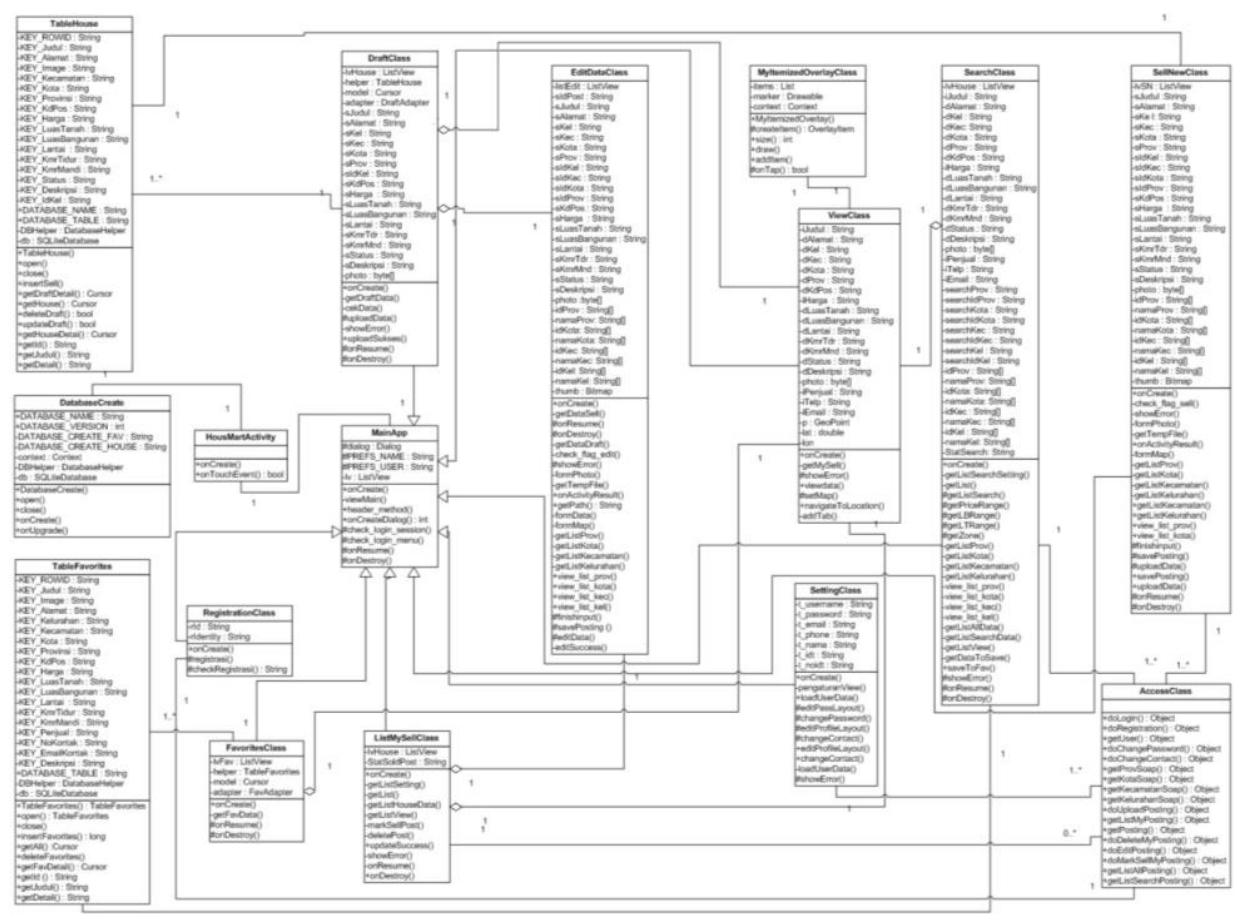

Fig. 3: System design of the application 


\section{Result and Evaluation}

The following is the HousMart application result in the form of screenshots on the Samsung Galaxy A50s mobile phone with the Android 9 OS (Pie) operating system. When the user opens the HousMart application, a splash screen appears with the HousMart logo, as shown in Fig. 4. The splash screen closes automatically and loads the homepage before the user logs in page. Users can log in by pressing the Login button or register using the Register button in the header. The home page consists of three main menus, namely Selling Houses, Favorites and files. The "house for sale" menu is used to fill in-home data for sale by the user (seller). The favorite menu is a list of homes marked as favorites by the user (buyer).

The home page shown in Fig. 5 loads after the user has logged into the application. Users have the ability to log out by pressing the Keluar button found in the header. This page consists of several menus similar to the homepage before logging in and three additional menus, namely Search for a House, Register for My Sale and Account Settings. The Home Search menu is used to search home data needed by the user (buyer). My Sales-List menu is a menu used to visualize the list of sold houses. Account Settings Menu is used to edit user account data (sellers and buyers).

Figure 5 shows the Registration page, which enables buyers and sellers to fill in their personal data in the form of username, password, name, email, telephone number and identity number according to the type chosen, followed by pressing the Daftar Sekarang button. Users are also able to easily cancel the process using the Kembali button. The username and password entered are used to login into the application.

The Sell house page appears after selecting the Sell House menu, as shown in Fig. 6. This page has three menus, namely, Enter Photo, Enter Data and Enter Region. When the user selects the Insert Photos menu, the application enables them to enter home photos. Users also take new photos by pressing the Ambil Foto Baru button. They are also able to insert photos contained in the Gallery of their cellphones by pressing the Buka Galeri button. Photos that have been taken will appear on the Insert page. When users select the Enter Data menu, the application displays an Enter Data page where they are asked to fill in-home data, including Title, Address, Postal Code, Price, Land Area, Building Area, Number of Floors, Number of Bedrooms, Number of Bedrooms Bathroom and Description. Users are mandated to fill in at least the Title and Address to save data to the file. When they choose to Enter Region menu, the application displays the page where they are asked to select data on the home area, such as Province, City, District and Village. Regional data are automatically provided.

Users that have not finished filling out data on all three forms on these menus have the ability to save home data to file by pressing the Simpan ke Berkas button. However, assuming they have finished filling out all data, the user is opportune to upload the house data by pressing the Upload button.

The Search Home page appears after selecting Cari Rumah menu. This page comprises of two menus namely, Cari Rumah and Berdasarkan Kriteria. The Lihat Semua Rumah menu displays a list of all houses page that contains all houses, as shown in Fig. 7. The Berdasarkan Kriteria menu displays the Buat Kriteria page. Users have the ability to create criteria according to the Price Range, Range of Building Area, Range of Land Area and House Area. The Kisaran Harga menu displays price range criteria page as shown in Fig. 7. Users are asked to fill in the price range from zero to up to several rupiahs and then press the Selesai button. The Kisaran Luas Bangunan menu displays the building area range criteria page as shown in Fig. 7. Users are asked to fill in the range of building area in $\mathrm{m}^{2}$ before pressing the Selesai button. The Kisaran Luas Tanah menu displays the land range criteria page as shown in Fig. 7. Users are asked to fill in the range of land area in $\mathrm{m}^{2}$ before pressing the Selesai button. The Masukkan Daerah menu displays the enter region criteria page as shown in Fig. 7. Users are asked to choose a range of regions such as province, city, kecamatan, or kelurahan. After creating search criteria, the user presses the Lakukan Pencarian button to look for houses according to the desired criteria. Searches conducted from the Berdasarkan Kriteria menu display a home list page that matches the criteria entered. Users also have the ability to mark the home favorites after conducting searches. Furthermore, a home is selected from the search results, with the options menu displayed in Fig. 7 before selecting the Tandai Favorit.

The Favorites menu displays a page that contains a list of previously favorite homes, as shown in Fig. 7. Users have the ability to open the options menu by selecting one of their favorite data, which is displayed in the options menu. On the options menu used to delete data is Hapus. The Daftar Jualanku menu display contains a list of houses sold by users. This page has two menus, which are Belum Terjual and Terjual. Users are enabled to choose one of the menus to visualize a list of sold or unsold homes. The Belum Terjual menu displays a Daftar Belum Terjual page which lists houses that users have sold. These houses are sold or deleted from their sales list by selecting one of the data. The Hapus menu on the options menu deletes data that was previously selected from the sales list. Selection menu Tandai Terjual on the options menu changes the house's status from "for sale" to already sold to prevent it from appearing in the home search process. The Edit options menu displays an Edit file page with several menus. This page consists of three menus, namely the Edit Foto menu, the Edit Data menu and the Regional Edit menu. The Edit Foto menu displays the Photo Edit page used to change photos of the house that 
have been saved in the file. The user can choose to take a new photo by pressing the Ambil Foto Baru button or enter a photo contained in the phone gallery by pressing the Buka Galeri button, then selecting the photo to be included. The Edit Data menu displays the Edit Data page to change the house data that has been saved in the file, including Title, Address, Postal Code, Price, Land Area, Building Area, Number of Floors, Number of Bedrooms, Number of Bathrooms and Description. When the user selects the Edit Regional Menu, the application displays the associated page, enabling them to change the home area's data (Province, City, District and Village). Changes to the data are made by pressing the Ganti Daerah button and then new regional data is provided automatically. The Daftar Sudah Terjual menu lists the homes that the user has sold. The user has the ability to delete a house from its sale list by selecting data from the unsold list, then displaying the options menu and selecting the Delete menu option.

The elaboration of the results of the Eight Golden Rules of User Interface Design is as follows. The HousMart application seeks to maintain consistency in terms of appearance, including layout, color, header and writing. It provides the main menu that makes it easy for users to access all parts of the application. Furthermore, this application is designed to provide informative feedback for each action taken by the user. For example, an area data on the Selling Houses page is entered, a warning appears, which is connected to the internet. The HousMart application displays a final message to the user when home data is deleted from the Favorites menu, file, My Sale List and other actions. The HousMart application provides information to prevent users from filling invalid data. For example, on the Enter Data page on the Sell House menu, when the user makes a mistake in filling in the data, an error message appears. The HousMart application provides a "Back" button on each menu and submenu within the application. It also gives users the freedom to navigate as they wish by selecting the menus provided without following a specific navigation sequence. Furthermore, it uses icons that do not confuse the user and the menus provided are written in easy-tounderstand language.
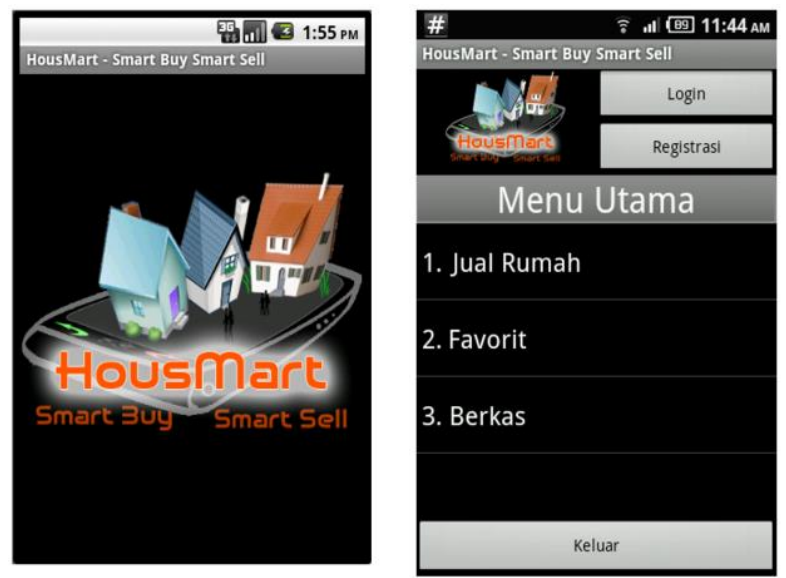

Fig. 4: Opening and main menu screen of the application
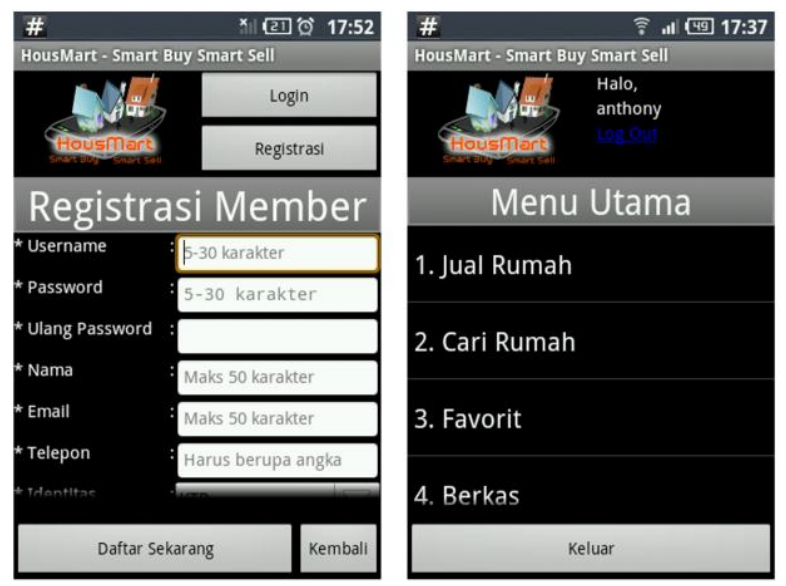

Fig. 5: Home screen after login and register page 
Bayu Kanigoro et al. / Journal of Computer Science 2021, 17 (8): 683.691 DOI: 10.3844/jessp.2021.683.691
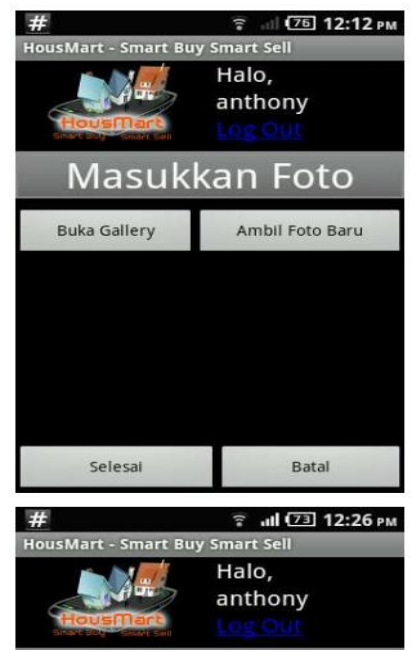

Masukkan Daerah

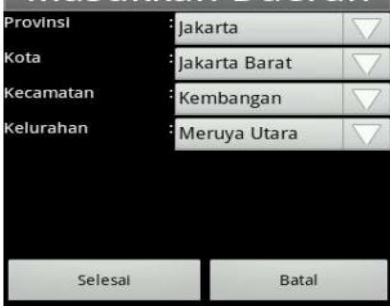

Fig. 6: Sell house page with three sub-menus

CNat?
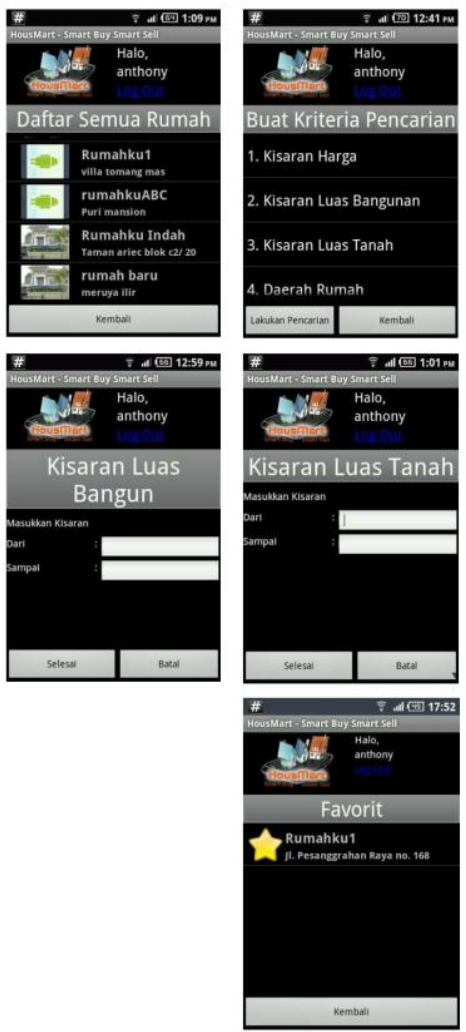

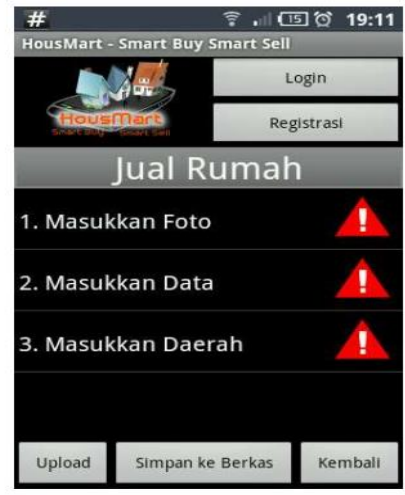

\# $17: 50$

\#
HousMart - Smart Buy Smart Sell

trovismars

Masukkan Data

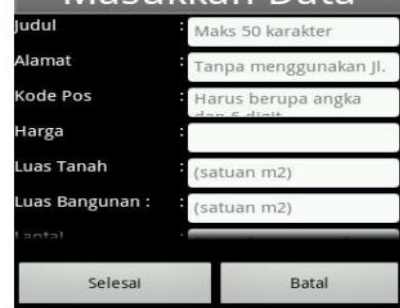

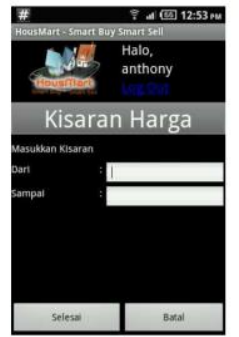
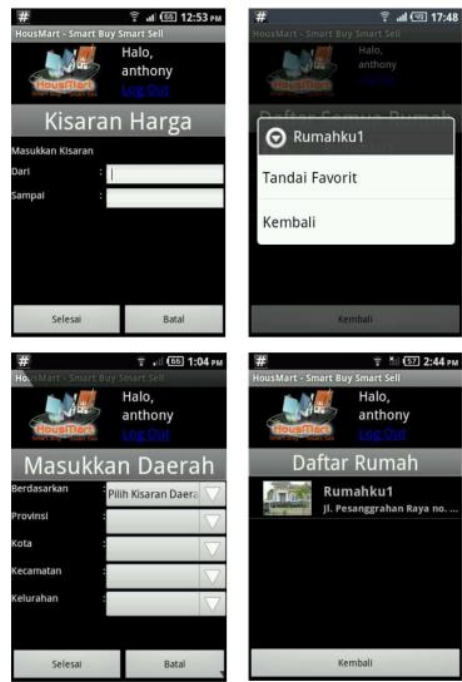

Fig. 7: Search home page with three sub-menus and favorit page 


\section{Conclusion}

In conclusion, based on the implementation results associated with evaluating the House Mart application, it is concluded that this Android-based software helps people get accurate, easy and fast information about their homes. The HousMart application is a flexible alternative promotion media for home sellers. The next features of this application aim to support wider scope of houses in terms of types and location, with users' ability to comment and send private messages. It also aims to provide options for seller rating, photo gallery and tax calculation.

\section{Acknowledgment}

The authors are grateful to Penelitian Terapan Binus for supporting this research through the 2019 grant.

\section{Author's Contributions}

Bayu Kanigoro: Contributing on writing, proofreading, conducting experiment and development of the application and data analysis.

Afan Galih Salman: Research plan and organized the study. Review and suvervised the research.

Anthony: Programmer of the application, conducting experiment and development of the application.

\section{Ethics}

This article is original and contains unpublished material. The corresponding author confirms that all of the other authors have read and approved the manuscript and no ethical issues involved.

\section{References}

Bauer, C. \& King, G., (2005). Hibernate in action (Vol. 1). Greenwich CT: Manning.

Chen, E., \& Liu, M. (2009, July). Research and Design on Library Management System Based on Struts and Hibernate Framework. In 2009 WASE International Conference on Information Engineering (Vol. 2, pp. 310-313). IEEE. https://doi.org/10.1109/ICIE.2009.161

Connolly, T. M., \& Begg, C. E. (2010). Database Systems: A Practical Approach to Design, Implementation, and Management. Boston: Pearson Education
Darmansyah, D., Parpati, P., \& Gunawan, R. (2021). Perancangan Aplikasi Mobile E-Marketplace Rumah Kost (Studi Kasus: Kabupaten Karawang). Jurnal Interkom: Jurnal Publikasi Ilmiah Bidang Teknologi Informasi dan Komunikasi, 15(4), 24-36.

Kangasharju, J., Tarkoma, S., \& Raatikainen, K. (2003, September). Comparing SOAP performance for various encodings, protocols and connections. In IFIP International Conference on Personal Wireless Communications (pp. 397-406). Springer, Berlin, Heidelberg. https://doi.org/10.1007/978-3-540-39867-7_38

Knuth, D.E (1973). The Art of Computer Programming : Searching and sorting, Addison-Wesley

Konda, M. (2014). Just Hibernate: A Lightweight Introduction to the Hibernate Framework. " O'Reilly Media, Inc." ISBN-10: 1449334350.

Kurniawan, D. E., Janah, N. Z., Wibowo, A., Mufida, M. A. K., \& Prasetyawan, P. (2018). C2C marketplace model in fishery product trading application using SMS gateway. In MATEC Web of Conferences (Vol. 197, p. 15001). EDP Sciences. https://doi.org/10.1051/matecconf/201819715001

Liu, Y. L., \& Xiong, X. M. (2014). A pushlet system optimization method based on Servlet. In Applied Mechanics and Materials (Vol. 596, pp. 899-902). Trans Tech Publications Ltd. https://doi.org/10.4028/www.scientific.net/AMM. 596.899

Owens, M. (2006). The definitive guide to SQLite. Apress. ISBN-10: 143020172X.

Pressman, R. S. (2005). Software engineering: A practitioner's approach. Palgrave macmillan. ISBN-10: 007301933X.

Kharisma, A. (2011). What is Android. In Android Developers.

Shanker, A., \& Lai, S. (2011, April). Android porting concepts. In 2011 3rd International Conference on Electronics Computer Technology (Vol. 5, pp. 129-133). IEEE. https://doi.org/10.1109/ICECTECH.2011.5941971

Steelman, A. (2008). Murach's Java Servlets and JSPs. Learning, 6, 7 .

Wu, Q., Hu, Y., \& Wang, Y. (2010, May). Research on data persistence layer based on hibernate framework. In 2010 2nd International Workshop on Intelligent Systems and Applications (pp. 1-4). IEEE. https://doi.org/10.1109/IWISA.2010.5473743 